\title{
Negotiating Dataveillance in the Near Future: Margaret Atwood's Dystopias
}

\section{Claire Wrobel}

\section{Q OpenEdition}

1 Journals

Electronic version

URL: https://journals.openedition.org/ces/7718

DOI: 10.4000/ces.7718

ISSN: 2534-6695

Publisher

SEPC (Société d'études des pays du Commonwealth)

\section{Electronic reference}

Claire Wrobel, "Negotiating Dataveillance in the Near Future: Margaret Atwood's Dystopias",

Commonwealth Essays and Studies [Online], 43.2 | 2021, Online since 23 July 2021, connection on 03

February 2022. URL: http://journals.openedition.org/ces/7718 ; DOI: https://doi.org/10.4000/ces.7718

This text was automatically generated on 3 February 2022.

\section{(c) (i) (3)}

Commonwealth Essays and Studies is licensed under a Licence Creative Commons Attribution - Pas d'Utilisation Commerciale - Pas de Modification 4.0 International. 


\title{
Negotiating Dataveillance in the Near Future: Margaret Atwood's Dystopias
}

\author{
Claire Wrobel
}

1 Imagining what comes next is the stuff that Margaret Atwood's dystopian novels are made of. ${ }^{1}$ In retrospect, The Handmaid's Tale (1985) may seem to have been prescient. While it may be read in the context of the backlash against feminism in the United States in the 1980s (Neuman 2006), it has gained new significance in the misogynous context of the Trump administration. The handmaid's outfit, with its scarlet robe and white cornet, has become a visual rallying cry for women protesting against attempts on their reproductive rights in places as diverse as Texas, Northern Ireland or Argentina (Beaumont and Holpuch 2018). Atwood's awareness of the threat that uncontrollable viruses constitute may also seem prescient in light of the ongoing pandemic. Thus, the explanations offered for the fertility crisis in the same novel include the spread of "a sterility-causing virus that was developed by secret pre-Gilead gene-splicing experiments with mumps" (321). Reading the last pages of Oryx and Crake, which describe the human race being wiped off the surface of the earth by a global pandemic in a context where climate change has already happened, did make for chilling and yet cathartic reading during the first lockdown in France in March 2020. ${ }^{2}$ Atwood, who has acquired a reputation for being a "buoyant doomsayer," "loves to entertain notions of how degraded our future might become" and her fiction has explored current and looming crises - whether social, political, economic, environmental, or health-related - for a long time (Mead 2017, §51, §5). However, she herself has warned against making hasty comparisons, for instance, between her totalitarian regimes and the governments imposing restrictions on liberties and increased surveillance across the world in the face of the COVID-19 pandemic (Flood 2020).

2 Surveillance has been a long-standing concern of Atwood's futuristic fiction, with George Orwell's Nineteen Eighty-Four and Aldous Huxley's Brave New World as forebears. 
In Atwood's analysis, although Huxley's version of "man-made hell" ("control through conditioning and consumption") seemed to have triumphed after the disintegration of the Soviet Empire, the response to 9/11 (in which "state surveillance is back with a vengeance") has revived Orwell's version ("control by terror"), the result being a combination of the two: "open markets, closed minds" (Atwood 2011, 90, 148). Atwood's diagnosis aligns with the identification by surveillance scholars of a "post-Orwellian collusion of governmental and corporate forces" (Lyon 2018, 12; the point is also made by Harcourt 2015 and Zuboff 2019). Even authors who warn against the paranoid tendency to believe that "any State surveillance is oppressive and - more dubious still indicative of broader, coercive objectives" find grounds for concern in commercial surveillance, especially when consumers have no choice but to accept monitoring in order to have access to essential services, when governments outsource intelligence gathering to corporations and when legislatures and courts fail to regulate information sorting (Rosen and Santesso 2013, 241-43; original emphasis). Atwood's fiction stages such state/corporate hybrids, embodied for instance in The Heart Goes Last in Ed, the leader of the Consilience/Positron project who is part Big Brother and part businessman. This article will focus on the grab for personal data in surveillance societies, and show how Atwood's fiction registers the advent of ever-more intrusive technology in the context of an increasingly digital culture, anticipating the directions it may take from there while highlighting pitfalls, blind spots and contradictions.

\section{From dystopia to post-apocalyptic fiction}

Before turning to the question of surveillance specifically, this section tries to determine what future exactly Atwood's fiction engages with - how close or remote is it? How does it reflect back on the present? In her 2011 essay on science fiction, Atwood described The Handmaid's Tale, Oryx and Crake, and The Year of the Flood as "full-length fictions that nobody would ever class as sociological realism" (2). The fact that such works cannot be classified as "sociological realism" does not preclude them from holding a critical mirror to contemporary Western society; quite the contrary. Their dystopian quality gives them critical, sometimes satirical depth and enables them to explore contemporary anxieties. They pick up on existing potentialities and imagine a future in which the latter are fully operational, extrapolating on the basis of "things that really could happen but [haven't] completely happened" or the "seeds of what might become the future" (Atwood 2011, 6, 61). Atwood does not claim to be a prophet and defines the "other worlds" she explores in her books as "our own planet in a future," a phrase in which the indefinite article is important since "the future is an unknown: from the moment now, an infinite number of roads lead away to 'the future', each heading in a different direction" (Atwood 2011, 5). The focus of speculative fiction, for Atwood, is human society (115). She coined the word "ustopia" to highlight the dialectic relationship between utopia ("the imagined perfect society") and dystopia ("Great Bad Places" characterized by "suffering, tyranny and oppression of all kinds") because "each contains a latent version of the other" following a "yin and yang pattern": "within each utopia, a concealed dystopia; within each dystopia, a hidden utopia" $(66-67,85)$.

4 In the novels studied here, time is organized around collapses and catastrophes. They begin after long-running changes and forces - whether environmental, political, 
economic or social - culminate in a violent upheaval that nearly destroys a previous social order which Western readers can identify as theirs. In The Handmaid's Tale, a coup orchestrated in Washington by Christian fundamentalists establishes the Gilead theocracy, which relies on a combination of brutal force and surveillance to control the population, and forces fertile women into child-bearing in a context where environmental pollution has led birth rates to plummet. After the shooting of the President and of Congress (a killing blamed on "Islamic fanatics"), a state of emergency is declared, the Constitution is suspended, newspapers are censored or even closed down, all in the name of security and with little protest on the part of the population: "Everyone approved of that, since it was obvious you couldn't be too careful" (Atwood 1996, 183). Parallels have been drawn between this fictional approval and the response to increased state surveillance in the wake of the 9/11 attacks.

In The Heart Goes Last, which was written with the 2008 crisis in mind, the triggering event is a "big financial-crash business-wrecking meltdown" (Atwood 2016, 5). The protagonists, Stan and Charmaine, find themselves jobless and homeless overnight, living in their car, at the constant mercy of zombie-like robbers. In that context, the Consilience/Positron project they join appears like a utopia, a perfect world in which the problems of crime and joblessness can be solved. The scheme, a "wonderful model community" (119), is presented as an "ultra, ultra important experiment" which can bring "salvation" to the whole nation (44-45). Like all utopias, the scheme is selfcontained, as suggested by the recurrent image of the egg $(51,234)$. The dystopic element is that Positron, the prison, is the core of society - the "yolk," "the jewel in the middle of Consilience," "the core, the heart, the meaning of it all" $(51,147,234)$. In that novel, Atwood "takes the premise of for-profit prisons to monstrous, comic ends" (Mead 2017, \$47). Indeed, prisons have been turned into "win-win viable economic units" which contribute to an "ever-flowing cornucopia of jobs" for participants who spend half their time in Consilience and the other half in Positron (48-49). By the end of the novel, the scheme has become a profitable franchise, "like hamburger chains, only with prisons," and greed has turned utopia into dystopia (287). Prisons operate in economic symbiosis with retirement homes where aging millionaires offer a bottomless market for the organs, bones and DNA which the twin cities produce by putting to death criminals and, once that population has run out, regular participants.

Chronology is bounded by the eventual collapse of the dystopian regimes. Gilead's demise is hinted at in the Historical Notes at the end of The Handmaid's Tale and explained in The Testaments while the collapse of the Consilience/Positron project joined by Stan and Charmaine is told in just a few lines, without further details regarding the other projects or the "chain." The MaddAddam trilogy goes further, both in terms of narrative time and in the scale of the disaster. It is often described as "postapocalyptic" since a bioengineered hemorrhagic virus wipes out most of the human race in a context where environmental disaster has become everyday reality. The "world before" is a dystopic near future in which social divisions have materialized in the walls that separate Compounds (gated communities where businessmen and elite scientists researching genetic modification live in luxurious conditions) from the Pleeblands (urban ghettos where crime, poverty and disease are rife). The deadly virus has been engineered by Crake, who wants to destroy human kind - including himself in order to make way for his improved posthumans, nicknamed the "Crakers." In the post-apocalyptic narrative present, the few survivors have to reinvent a form of society which includes the Crakers, and genetically modified, enhanced animals such as the 
"pigoons" (pigs with human DNA initially used to cultivate spare organs for human transplant surgery). The chaos which follows the pandemic can hardly be called dystopic, as dystopia requires an element of social organization, but the preapocalyptic past which corresponds to our near future certainly qualifies as a dystopia.

7 In all the novels considered here, narration goes back and forth between the characters' memories and their dystopic or postapocalyptic present. In The Handmaid's Tale, Offred remembers her pre-Gilead past and in The Testaments, which has three narrators, it is mostly through Aunt Lydia's memories that we are taken to the "time before"; in The Heart Goes Last, the narration alternates between Stan and Charmaine's lives at the time of the recession and their lives before; in Oryx and Crake and The Year of the Flood, the struggle of several characters - Jimmy, Toby and Ren - to survive in the postapocalyptic present is interwoven with flashbacks. As Katherine V. Snyder explains in her discussion of Oryx and Crake, speculative fiction "offers a particular and explicit challenge to its readers' sense of the temporal distance separating the fictional mise-enscène from the contemporary world" $(2011,470)$. Indeed, the dystopic extrapolation on trends in readers' present must look both familiar and different, meaning readers must have a kind of "double consciousness" and navigate between the different times (470).

Snyder notes that in Oryx and Crake, the vision of the future is characterized by a "dialectic between despair and hopefulness" (2011, 486). Generally speaking, in Snyder's analysis, “[p]ost-apocalyptic fiction serves as a rehearsal or preview for its readers, an opportunity to witness in fantasy origins and endings that are fundamentally unwitnessable. We are horrified and yet thrilled to see ourselves and our world in the unthinkable plight portrayed here, and yet even more horrified and thrilled to see the origin of this plight in ourselves" (479). Surveillance in Atwood's novels is intensive, all-pervasive and brutally discriminatory. Readers are offered a glimpse into worlds where it is depicted as fully operational in the near future but they are also led to wonder whether the near future has not already happened. The thrill of horror may come with a shock of recognition as readers try to assess the distance - or lack thereof - which separates their society from the fictional world. The seeds of surveillance society are already present in the characters' past. Thus, in The Handmaid's Tale, offred remembers how debit cards came to replace actual money entirely. Atwood's research archives include cuttings of reports about the threat to privacy posed by such cards, which were a novelty at the time (Mead 2017, \$12). Similarly, in The Heart Goes Last, Stan remembers giving up his privacy before the meltdown. Caught in the "electronic net," he had allowed himself to be reduced to "a series of numbers, stored by others, controlled by others" (Atwood 2015, 187). Finally, the world that provides the background to Jimmy's childhood memories in Oryx and Crake is surveillance-ridden. The specificity of the novel - and the whole trilogy - is that surveillance is already a thing of the past. Since surveillance systems collapse along with the whole social fabric, "the post-human world seems also a post-surveillance world" (Marks 2015, 114). Therefore, surveillance is not set up by dystopian regimes. The latter use already existing surveillance to upset the established order and maximize it to assert their hegemony, as illustrated by the way they appropriate and control personal data. 


\section{Welcome to the age of dataveillance}

9 Surveillance has been defined as the "purposeful, routine, systematic and focused attention paid to personal details, for the sake of control, entitlement, management, influence, or protection" (Murakami Wood et al. 2006, 4). Far from being a monolithic concept or practice, it may be described "through a plurality of modes (security agents, policemen, videosurveillance, biometrics, geolocation, RFID chips, etc.), roles (surveillor/surveilled) or ends (security- or economy-related, functional etc.)" (Castagnino 2018, 11; my translation). David Lyon warns that "digital devices only increase the capacities of surveillance or, sometimes, help to foster particular kinds of surveillance or help to alter its character" $(2007,15)$. Similarly, Rosen and Santesso caution readers against a "technological determinism" according to which "each new advance in data mining or miniaturization [is] understood as producing inevitable harmful results" $(2013,3)$. Indeed, surveillance operates on a spectrum that goes from care to control (Lyon 2001), "from watching over one for purposes of protection to scrutinizing one's behavior in order to enforce discipline" (Monahan 2011, 497) and is not necessarily inherently malevolent although it is "ever amenable to ethical assessment" because "[p]ower relations are always present, for better or for worse" (Lyon 2018, 17).

10 Technological evolutions have been registered in Atwood's dystopias since the 1980s. The Handmaid's Tale, which she started writing in Berlin in the spring of 1984, has Cold War undertones, with its secret police driving around in black vans, a system of passes for identification, and controls at checkpoints and borders, ${ }^{3}$ but, as noted above, it also responds to the appearance of debit cards. Surveillance cameras are introduced in the novel's sequel, placed by Aunt Lydia to monitor the population inside Ardua Hall, and are omnipresent in The Heart Goes Last as well as in the MaddAddam trilogy. A technological threshold has clearly been crossed in the novels published in the twentyfirst century, with DNA collection and the use of biometrics (retina scans, fingerprints, voiceprint) to establish identity, electrodes and facial-expression analyzers to monitor emotions, the tracking of movements with drones and the use of cellphones, computers and internet browsing to gather personal information and track users. And yet, despite or in addition to their technological awareness, Atwood's novels also analyze the psychological springs of surveillance, such as brainwashing-induced self-surveillance, peer surveillance and "control of the indigenous by members of their own group" in The Handmaid's Tale (Atwood 1996, 320), and social mechanisms such as social sorting, which is the "sort[ing of] people into categories, assigning worth or risk" using factors such as gender, class or race to discriminate and discipline, often used in risk management (Lyon 2003, 1).

11 The development of dataveillance, i.e. "the systematic monitoring of people or groups, by means of personal data systems, in order to regulate or govern their behaviour" (Clarke 1987, quoted in Andrejevic and Gates 2014, 190), is usually presented as a quantitative and qualitative leap - quantitative as regards the amount of data that can be processed and qualitatively in that it may be used for predictive purposes. It is inseparable from new computer technologies. Haggerty and Ericson borrow the concept of "assemblage" from Deleuze and Guattari (in A Thousand Plateaus, 1980) to highlight "a convergence of what were once discrete surveillance systems to the point that we can now speak of an emerging 'surveillant assemblage'," prompted by "the 
desires for control, governance, security, profit and entertainment" $(2000,606,609)$. Surveillance turns human bodies into "discrete flows" which are then "reassembled into distinct 'data doubles' which can be scrutinized and targeted for intervention" (606). The monitored body becomes a cyborg, a "flesh-technology-information amalgam": "These hybrids can involve something as direct as tagging the human body so that its movements through space can be recorded, to the more refined reconstruction of a person's habits, preferences and lifestyle from the trails of information which have become the detritus of contemporary life" (611).

More recently, Shoshana Zuboff has shown how "our lives are unilaterally rendered as data, expropriated, and repurposed in new forms of social control" (2019, 54-55). Human lives are rendered as "behavioral data for the sake of others' improved control of us," in the shape of an electronic text:

Thanks to our computers, credit cards, and phones, and the cameras and sensors that proliferate in public and private spaces, just about everything we now do is mediated by computers that record and codify the details of our daily lives at a scale that would have been unimaginable only a few years ago. $(94,181-82)$

In her analysis, the years 2001-2002 are pivotal. They correspond to the discovery of "behavioral surplus" by Google (meaning meta-data which can be used to predict future behavior) and to the beginning of the "war on terror," a context which led governments to take "an urgent interest in the rapidly developing skills and technologies of Google and other rising surveillance capitalists" (340). While Atwood's novels do not tackle the corporate surveillance described by Zuboff, several points in the latter's analysis are worth keeping in mind when reading Atwood's work, notably the "ever-more-predictive sources of behavioral surplus," namely "our voices, personalities, and emotions" (8) and the social division between the "exclusive data priesthood" and the majority of the population who provides the raw behavioral material (81). Indeed, personal - down to biological - intrusiveness and social exclusion characterize the power held by the elite scientists in the Compounds described in Oryx and Crake, for instance.

13 The establishment of dystopia depends on the collection of personal information and observation, combined with social sorting. Debit cards offer the means by which the Gilead regime tracks women and makes them dependent on their male relatives again. At the time of the coup, "portable money" had disappeared and all bank accounts started with an M or an F depending on the individual's gender (Atwood 1996, 183). Shutting down women's bank accounts, transferring their money to male relatives and ousting them from their jobs only required "push[ing] a few buttons" (187). In The Testaments Aunt Lydia describes how women in her office were sent to three different places (the box store, the high school, the stadium) depending on their occupation and level of fertility, and therefore potential utility for the regime. Once established, Gilead continues to rely on social sorting, which is used to identify (by means of uniforms with specific colours), but also exclude and discriminate: being reclassified as an "Unwoman" or "gender traitor" - i.e. a homosexual as well as, in The Testaments, a crossdresser - means being shipped off to the Colonies to clean toxic waste.

Social sorting also lies at the origin of Consilience/Positron. Stan understands that would-be participants are put under invisible observation during the selection process: “they're being scrutinized, though it's hard to figure out who's doing it" (Atwood 2016, 38). He is aware of a "discreet weeding" throughout the evening: "All those with bad attitudes, out the Discard door" (39). This process will become even more sinister when 
the Special Procedure is performed on "misfits": "the worst criminals, the incorrigibles, the ones they haven't been able to turn around [...] [t]he troublemakers, the ones who'd ruin Consilience if they had the chance" (85).

The next steps in the establishment of the dystopian regime include further collection of personal data, the issuance of identification documents ("Identitypasses" in Gilead) and continued monitoring. Handmaids are assigned numbers which are tattooed onto their ankles: "Four digits and an eye, a passport in reverse" (Atwood 1996, 75). They are subjected to medical monitoring: "urine, hormones, cancer smear, blood test; the same as before, except that now it's obligatory" (69). Their intake in vitamins is controlled; they are not allowed to have coffee or alcohol; and their diet is monitored by the other servants. Thus, Offred is afraid Cora may report her lack of appetite (76). In a sense, Offred experiences the effects of biopolitics at the individual level, but Atwood does not give us an idea of how the individual information is assembled and mined. In The Heart Goes Last, on the other hand, the central database plays a prominent role.

After would-be participants go through the "shiny black-glass wall" (Atwood 2016, 30) that surrounds the twin cities of Consilience and Positron, biometric information (retina scans, fingerprints, voice analysis) is collected and entered into the database which issues code identities: "a plastic passcard with a number on it and a barcode" (38). If the cards and codes are "deactivated," as happens to Charmaine, the person is "in limbo" (118). A piece of code can therefore lead to disappearance from the system. The data double takes precedence: “numbers are numbers, and her numbers aren't showing her as being who she says she is"; "Positron identity numbers don't lie, the system's hackproof" (120-21; 123-24; original emphasis) Here, literature goes further than social science in imagining that data doubles may actually acquire an autonomous existence of their own, as suggested by Aurora's supposedly reassuring words: “This isn't about you personally [...]. It's your data" (119). As Charmaine realizes, disappearing from the database amounts to being dead - "a blank line in the databank" - and Stan understands early enough that "Jocelyn [the head of the surveillance system] could erase him": "She could just wave her hand and reduce him to zero" $(216,137)$. When Charmaine recovers her "code identity", she is brought back to herself: "[S]he is now once again who she's been claiming she is" $(140,139)$. This episode shows the dangers but also the vulnerabilities of the surveillant assemblage.

In the MaddAddam world, the Compounds are surveillance-intensive, both at their borders, meant to seal off the pleeblands, and within (with strip searches, bugging of phones and emails, spying by house staff, night patrols, curfews and sniffer dogs). But CorpSeCorps surveillance also extends beyond. In Oryx and Crake, it appears that they have tracked Jimmy's mother, who has joined the bioterrorist resistance movement, in "stills from buttonhole snoop cameras, or blacks-and-whites that looked as if they'd been pulled off the security videocams at pleebland bank ATMs" (Atwood 2003, 256). In The Year of the Flood, the CorpSeCorps are reported to use official marriages as opportunities to "captur[e] your iris image, your fingerscans, and your DNA," the better to track down activists: "[O]nce you were in their system you never got out of it except by turning up as a corpse with dental work and DNA that matched their records" (Atwood 2010, 115, 267). As Paul Hamann comments, the "pervasive, corporate-run surveillance system [...] entails an anti-democratic commodification of personal data," leading to a shift in the stakes of privacy which is now defined as "an individual's power to control the use of their genetic information" (Hamann 2019, 62- 
63). This system relies on the idea that genetic data is the "final marker of identity" (Hamann 2019, 76), but this premise is questioned in the strategies deployed by characters to avoid dataveillance.

\section{Counter-surveillance strategies}

18 The field of surveillance studies has been noted for its tendency to focus on vertical relations and to underestimate the critical abilities of individuals who are often presented as powerless in the face of present or future dystopias (Castagnino 2018, 27, 28). This "negative ontology" consists in exaggerating the rationality of power and its exercise (13). Monahan too insists on the necessity to "[r]ecogniz[e] the agency of the watched [...] even if resistance sometimes confirms, more than challenges, the reach of abstract systems of control" $(2011,498)$. While sociology underestimates agents' ability to resist surveillance techniques, Atwood's fiction depicts individuals whose general struggle to survive includes resisting omnipresent surveillance. As the novels do not give overviews from above, readers, through the characters' eyes, discover the dystopian worlds "in gasps" (Atwood 1996, 40) and resist surveillance at their microlevel, although there are allusions to organized networks of resistance, such as the Underground Female Road in The Handmaid's Tale and the MayDay operation, presented in further detail and from the Canadian side in The Testaments. The subjective position of characters caught in the meshes of surveillance systems offers a perspective which goes against - or maybe complements - the "top down" approach which prevails in surveillance studies.

In "A Tack in the Shoe," Gary T. Marx describes eleven behavior techniques of neutralization intended to subvert the collection of personal information. His premise is that "[i]n Western liberal democracies the advantages of technological and other strategic surveillance developments are often short-lived and contain ironic vulnerabilities" $(2003,369)$. Some factors work against the establishment and smooth running of surveillant dystopias, such as "practicality, cost, laws and fears of lawsuits, organizational policies, morality, doubts about effectiveness or the ability to control the technology, and concern with public opinion" (371). He also notes "a gap between visible conforming behavior and less visible attitudes, emotions, and fantasies" (371). All in all,

human creativity seeking to thwart systems of surveillance is aided by logistical and economic limits on total monitoring, the vulnerability of those engaged in surveillance to be compromised, and the interpretive and contextual nature of many human situations. (373)

Similarly, Rosen and Santesso point to the fact that even though the State may collect significant amounts of personal data and issue identification documents, it simply "lacks the time and manpower to micromanage each participant" $(2013,243)$.

Three of the techniques Marx identifies are particularly relevant to Atwood's novels, namely blocking, masking and counter-surveillance moves. Since "[s]urveillants desire to read the signals given off by their subjects," the latter may decide to resort to "blocking": "With blocking, subjects seek to physically block access to communication or to render it (or aspects of it such as the identity, appearance or location of the communicator) unusable" (Marx 2003, 379). The call to avoid leaving "the trails of information which have become the detritus of contemporary life" (Haggerty and Ericson 2000,611) echoes across the various novels studied here. In The Heart Goes Last, 
as Stan is exfiltrated outside Consilience/Positron, he is told to avoid "leaving trails" and to be "ready to wipe their whereabouts off the GPS very fucking quick" (Atwood 2013, 349). Leaving "no trails" and living "under the radar" are also tactics used in The Year of the Flood by the God's Gardeners, an environmentalist cult which has decided to live off the grid, and to do without cellphones altogether: "Don't even look at it: if you can see it, it can see you" (Atwood 2010, 6, 175, 67). Children are taught "Predator-Prey Relations," which include "Seeing without being seen" and "Hearing without being heard" (139). In MaddAddam, when Adam and Zeb go into hiding, they avoid "anything [...] with an electronic signal": text messages, phone calls, but also the internet which is scanned by DORCS - Digital Online Rapid Capture Specialists - who "set up a search algorithm geared to detect likely profile matches online" (Atwood 2014, 148-49, 157). The characters' blocking moves reflect Atwood's conviction, expressed in In Other Worlds, that "high-tech communication devices such as cell phones and computers [...] can be used to spy on you" $(2011,92)$.

In addition to shielding information and avoiding producing it, surveilled subjects may resort to "masking," which involves "deception with respect to the identity, status, and/or location of the person or material of surveillance interest." Not only is genuine information blocked, but misleading information is inserted, meaning that "the surveillance mechanism operates as intended but the information collected is misleading and useless" (Marx 2013, 380). Atwood's dystopias depict ways in which identities can be usurped and systems defeated, so that "data doubles" are not final. Thus, in The Heart Goes Last, Jocelyn, who controls the identity codes, switches Phil and Stan and upsets the alternance system: "I've rearranged the data so Phil's going there in your place" (Atwood 2016, 105). Then, Stan's simulated death is registered in the database, where he no longer exists "except in the past tense," and he is given a new identity: "It's a databank move. [...] You're replacing a previous Waldo [...]. You're inheriting his code, his identity. I've gone into the system and spliced in your biometrics" $(163,205)$. In The Testaments, a similar swap is performed in the identification system used at the Canadian border. Daisy/Nicole's picture and physical data are associated with the identifying numbers of a deceased Aunt on a certified passport and the Canadian immigration database is hacked into so that her data, iris scan and thumbprint can be posted (Atwood 2019a, 270).

The masking and unveiling of identity are literary conventions which Atwood borrows from the detective novel and the spy novel, but she uses them to other ends, producing ironic and comical effects and deflating both surveillance and counter-surveillance, especially in The Heart Goes Last. Thus, in order to locate and pounce on his wife's alternate, whom he mistakenly believes to be a lustful creature called Jasmine, Stan decides to track her movements by inserting a smartphone in her scooter, using the Consilience interactive GPS. Not only is he wrong about her identity and caught "dabbling in digital experimentation" $(2016,101)$, but he is the one who gets walked on. Indeed, as he waits for his wife's alternate to appear, peering through a crack in the front door of the garage, he doesn't hear Jocelyn - his wife's actual alternate - enter by the side door, in a rather farcical scene (102). Stan's perception of Jocelyn's omnipotence as the head of the surveillance system produces grotesque images: "[S]he must have every one of her snatch hairs monitored, with a SWAT team ready to spring into lethal action at any threat" (127); "She can probably activate the alarm system by flexing her toes" (128). Conversely, in order to leak sensitive information outside 
Positron/Consilience, Stan has to first take up a former Waldo's identity - a new name which he receives with understandable incredulity - then be shipped off to Vegas dressed up as an Elvis sexbot, an outfit which will indeed enable him to defeat surveillance by hiding in the crowd of Elvises who throng the streets of the city without clocks. Neither dystopian regimes nor their information systems are entirely foolproof. In The Handmaid's Tale, Gilead's borders are actually unstable and offred hears about handmaids being smuggled over the border into Canada (Atwood 1996, 93), a porosity which provides a key narrative spring in The Testaments, with Rachel/Nicole going back and forth between the two spaces and the ever-increasing number of handmaids escaping becoming a political crisis for Commander Judd. A similar crisis builds up in The Heart Goes Last, where the leaders of the Consilience/Positron project unleash a wave of repression to identify and eradicate the journalists who have managed to "worm their way in" (Atwood 2016, 146). As for the Compounds of the MaddAddam trilogy, they are vulnerable to bioterrorist attacks.

Jocelyn and Aunt Lydia's position as masterminds of the surveillance systems gives them an advantage in tampering with the databases, including the biometric information they contain, but in the MaddAddam trilogy, genetic data can be sold and bought, stolen and subverted by anyone. In Oryx and Crake, identity can be forged and refashioned in the pleeblands north of New New York, which has a "Street of Dreams" where people "shop around" for "[g]ender, sexual orientation, height, colour of skin and eyes - it's all on order, it can all be done or redone" (Atwood 2003, 289). In The Year of the Flood, it is possible to get "the DNA infusion or the skin-colour change" as well as new fingerprints on the black market (Atwood 2010, 30, 119). Zeb and Toby, who are both on the run, acquire new identities and undergo alterations which go deeper than the "wigs, dyed hair, elevator shoes, padded clothing, plastic surgery or fake documents" listed by Marx as masking tools $(2003,380)$. Toby gets a new scalp, darker hair and skin, new fingerprints and voiceprint as well as face recontouring. The only limitation is changing the iris pigment so she has to wear contacts (Atwood 2010, 261). These changes enable her to "become more invisible" and "move into her new identity" (262-63). In MaddAddam, Zeb uses "fingerprints distorters" as well as contact lenses which change eye colour but also "gave you astigmatism and spurious features" (Atwood 2014, 158). He then gets a "plasti-cosmi job" on his ears, i.e. they are recontoured so they do not match photos (357). Atwood highlights the fact that biometric and genetic markers are inserted and interpreted within communication systems which are not error-proof.

Finally, counter-surveillance means "turning the tables and surveilling those who are doing the surveillance" (Marx 2013, 384), a strategy which is resorted to in several novels. When Charmaine becomes Ed's personal assistant in The Heart Goes Last, she is to "report back with anything he says and anything she might come across, for instance in his bureau drawers or his briefcase, or maybe on his cellphone," thereby becoming a "spy" (Atwood 2016, 266, 275). The God's Gardeners described in The Year of the Flood have "cells of hidden Exfernal sympathizers embedded at every level, even within the Corporations themselves," who provide information by which "the intentions and movements of their enemies could be monitored, at least in part" $(2010,189-90)$. When at the end of MaddAddam Zeb sends a message to the head of the Church of Petroleum revealing that his father - a leading figure of the same institution, which gives religious legitimacy to the Corporations - has committed murder and embezzlement, he signs the message Argus, "the hundred-eyes giant from Greek mythology," showing the 
extent to which surveillance has been reversed (Atwood 2014, 224). Similarly, in The Testaments, Aunt Lydia puts the elite under surveillance, keeping a record of "the secret histories of Gilead," an activity which explicitly puts her on a par with intelligence agencies (Atwood 2019a, 35). As she feels Gilead is about to collapse, a process which she deliberately speeds up, she collects a "stash of incriminating documents" (61). She has become "an ear inside the wall" to listen in on what young recruits tell one another, "increasing the sensitivity of [her] microphones" and "attun[ing] them to whispers" so as to collect the dirty secrets of Gilead (252). Atwood's conviction that totalitarian regimes always collapse translates into a narrative spring by which leaks and the reestablishment of transparency lead to their downfall (Atwood 2019b).

Some of the tricks used by Atwood's characters evoke anti-surveillance gadgets and wearables which have recently been designed, such as signal-jamming iPhone cases, the URME prosthetic mask supposed to help wearers fool biometric scanners or fingerprint-spoofing strips (Rogers 2016). Contemporary artists have also turned the tables and put cameras under surveillance, with for instance the iSee project (20012005), a web-based application that, in Brighenti's description, "maps the locations of surveillance cameras in urban environments" $(2010,145)$. Responses such as the CVDazzle project, which explains how to use hairstyles and make-up to confuse facial detection software, have however been criticized for being "an aesthetization of resistance, a performance that generates media attention and scholarly interest without necessarily challenging the violent and discriminatory logics of surveillance societies" (Monahan 2015, 160). More generally, Shoshanna Zuboff points out that countersurveillance strategies may constitute an acceptance or a normalization of surveillance, taking its existence for granted rather than challenging $i^{4}{ }^{4}$ and to some extent, such remarks apply to the strategies deployed on a thematic level in Atwood's work. On a textual level, however, the novels are very effective, especially through irony and humour, at deflating the "negative ontology" prevalent in surveillance studies (Castagnino 2018, 13) and the "rhetoric of inevitability" used by surveillance capitalists themselves (Zuboff 2019, 221).

This survey of Atwood's dystopian novels has uncovered a vision of surveillance which is closer to the "control" than the "care" end of the spectrum, and is necessarily selective. Some of the recent evolutions in the field are not tackled, such as the rise of facial recognition, the prospect of predictive policing and the development of random mass surveillance or the advent of social media and the voluntary sharing of personal information - with all the questions surrounding the insidious ways in which users are led to share such information and to offer their behaviour up for analysis by the same token. Surveillance is presented as targeted, as a means used jointly by state and corporations to take control over highly profitable personal data. Recent and predictable evolutions in surveillance do not seem to contradict Atwood's diagnosis regarding such a combination of state and corporate surveillance, and the depth and breadth of data which they may collect. The specificity of Atwood's work is that in the near future she depicts, the surveillance nightmare is hybridized with unfettered genetic experimentation and the commodification of the human body. The raw material which in Zuboff's analysis consists in human behaviour and social interactions therefore also includes in Atwood's novels bodily organs and genetic data. What is at stake is nothing less than human nature and human worth. 
There is no ambiguity as to the fact that the seeds of the extreme surveillance levels depicted in Atwood's fiction are present in the time that corresponds to her readers' present. Nevertheless, the dominant impression is not one of doom, since it is suggested that contrary to a widely shared perception that is encouraged by surveillant authorities and companies themselves, databases are not hackproof, data doubles are not final, and even genetic elements may be subverted. Because of our inherently ambivalent relation to surveillance and its systems, this vulnerability is both a threat and an opportunity, an ambiguity which is explored at the characters' level. The novels offer vicarious experiences of dystopian surveillance through the struggles of individuals who, in their local context and from their limited point of view, deploy effective strategies such as blocking, masking, and counter-surveillance so as to survive in hostile environments. The detour via the near future in literary fiction may hopefully provide an antidote to the "psychic numbing that inures us to the realities of being tracked, parsed, mined, and modified" (Zuboff 2019, 11) as well as against a paralyzing sense of inevitability.

\section{BIBLIOGRAPHY}

ANDREJEVIC, Mark, and Kelly GATES. 2014. Editorial. "Big Data Surveillance: Introduction." Surveillance \& Society 12, no. 2: 195-96.

ATWOOD, Margaret. 1996. The Handmaid's Tale. 1985. London: Vintage.

ATWOOD, Margaret. 2003. Oryx and Crake. London: Bloomsbury.

ATWOOD, Margaret. 2010. The Year of the Flood. 2009. New York: Anchor Books.

ATWOOD, Margaret. 2011. In Other Worlds: SF and the Human Imagination. London: Virago Press.

ATWOoD, Margaret. 2014. MaddAddam. 2013. London: Virago Press.

ATWOOD, Margaret. 2016. The Heart Goes Last. 2015. New York: Anchor Books.

ATWOOD, Margaret. 2019a. The Testaments. London: Chatto \& Windus.

ATWOoD, Margaret. 2019b. "Margaret Atwood on the Enduring Resonance of The Handmaid's Tale." National Public Radio, 10 September. https://www.npr.org/2019/09/10/759437597/margaretatwood-on-the-enduring-resonance-of-the-handmaid-s-tale.

BEAUMONT, Peter, and Amanda HOLPUCH. 2018. "How The Handmaid's Tale dressed protests across the world." The Guardian, 3 August. https://www.theguardian.com/world/2018/aug/03/how-thehandmaids-tale-dressed-protests-across-the-world.

BRIGHENTI, Andrea Mubi. 2010. “Artveillance: At the Crossroads of Art and Surveillance.” Surveillance and Society 7, no 2: 137-48.

CASTAGNINO, Florent. 2018. "Critique des surveillance studies. Eléments pour une sociologie de la surveillance." Déviance et societé 42, no 1: 9-40. 
CLARKE, Roger. 1987. Information Technology and Dataveillance. http://www.rogerclarke.com/DV/ CACM88.html.

FLOOD, Alison. 2020. "Margaret Atwood: Covid-19 lockdown is not a dystopia.” The Guardian, 16 April.

HAGGERTY, Kevin D., and Richard V. ERICSON. 2000. British Journal of Sociology 51, no 4: 605-22.

HAMANN, Paul. 2019. “Under Surveillance: Genetic Privacy in Margaret Atwood's MaddAddam trilogy." Journal of Literature and Science 6, no 4: 62-79.

HARCOURT, Bernard. 2015. Exposed. Desire and Disobedience in the Digital Age. Cambridge, MA: Harvard University Press.

HOWELLS, Coral Ann. 2006. "Margaret Atwood's Dystopian Visions: The Handmaid's Tale and Oryx and Crake." In The Cambridge Companion to Margaret Atwood, edited by Coral Ann Howells, 161-75. Cambridge: Cambridge University Press.

LYON, David. 2001. Surveillance Society: Monitoring Everyday Life. Buckingham, England: Open University Press.

LYON, David. 2003. Surveillance as Social Sorting: Privacy, Risk and Digital Discrimination. London: Routledge.

LYON, David. 2018. The Culture of Surveillance: Watching as a Way of Life. Cambridge: Polity.

MARKS, Peter. 2015. Imagining Surveillance: Eutopian and Dystopian Literature and Film. Edinburgh: Edinburgh University Press.

MARX, Gary T. 2003. “A Tack in the Shoe: Neutralizing and Resisting the New Surveillance.” Journal of Social Issues 59, no 2: 369-90.

MEAD, Rebecca. 2017. "Margaret Atwood, the Prophet of Dystopia." The New Yorker, 10 April. https://www.newyorker.com/magazine/2017/04/17/margaret-atwood-the-prophet-of-dystopia. MONAHAN, Torin. 2011. "Surveillance as Cultural Practice." The Sociological Quarterly 52: 495-508. MONAHAN, Torin. 2015. "The Right to Hide? Anti-Surveillance Camouflage and the Aesthetization of Resistance." Communication and Critical/Cultural Studies 12, no 2: 159-78.

MURAKAMI WOOD, David, Kirstie BALL, David LYON, Clive NORRIS, and Charles RAAB. 2006. A Report on the Surveillance Society. Wilmslow: Office of the Information Commissioner.

NEUMAN, Shirley. 2006. "'Just a Backlash': Margaret Atwood, Feminism and The Handmaid's Tale." University of Toronto Quarterly 75, no 3: 857-68.

ROGERS, S.A. 2016. "How to Be Invisible: 15 Anti-Surveillance Gadgets and Wearables.” Web Urbanist. 28 November. https://weburbanist.com/2016/11/28/how-to-be-invisible-15-antisurveillance-designs-installations/.

ROSEN, David, and Aaron SANTESSO. 2013. The Watchman in Pieces: Surveillance, Literature, and Liberal Personhood. New Haven: Yale University Press.

SNYDER, Katherine V. 2011. “'Time to go': the post-apocalyptic and the post-traumatic in Margaret Atwood's Oryx and Crake." Studies in the Novel 43, no 4: 470-89.

ZUBOFF, Shoshana. 2019. The Age of Surveillance Capitalism. The Fight for the Future at the New Frontier of Power. London: Profile Books. 


\section{NOTES}

1. The novels studied here include The Handmaid's Tale and its sequel The Testaments, which appeared in 1985 and 2019 respectively, The Heart Goes Last (2015) and the three volumes of the MaddAddam trilogy, namely Oryx and Crake (2003), The Year of the Flood (2009) and MaddAddam (2013).

2. These apocalyptic scenes found more immediate resonance with the $9 / 11$ attacks: "While Atwood was writing about a fictional catastrophe on the east coast of the United States in 2001, a real one occurred with the September 11 attack on the World Trade Center in New York, enhancing the eerily predictive quality of her dystopian visions" (Howells 2006, 161-62).

3. The microdot which is used to leak documents across the border with Canada in The Testaments is also a legacy from the Cold War.

4. "Glass life is intolerable, but so is fitting our faces with masks and draping our bodies in digitally resistant fabrics to thwart the ubiquitous lawless machines" $(2019,491)$; "It is not OK to have to hide in your own life" (521).

\section{ABSTRACTS}

Margaret Atwood's dystopias extrapolate from current trends, showing them as fully operational in the near future. They register the advent of ever-more intrusive surveillance in an increasingly digital culture which targets personal data. Characters who experience surveillance in local contexts, however, draw on a number of resistance strategies to keep control over personal data and take advantage of surveillance systems' ironic weaknesses.

\section{INDEX}

Keywords: Margaret Atwood, dystopia, surveillance, personal data, resistance

\section{AUTHOR}

\section{CLAIRE WROBEL}

Université Panthéon-Assas (Paris II) / VALE (Paris Sorbonne)

Claire Wrobel is Associate Professor in English at Panthéon-Assas University (Paris II). Her latest publication is entitled "At the Crossroads of Law and Literature: On the Role of Fiction in Jeremy Bentham's Penal Theory” (Law and Literature, 32, no. 3, 2020) https://www.tandfonline.com/doi/ full/10.1080/1535685X.2020.1725316. She recently co-organized a conference series on Surveillance and the Humanities with Australian National University (https://law.anu.edu.au/ event/virtual-conference/surveillance-humanities) and is currently working on contemporary literary rewritings of panopticism. 